\title{
PERANCANGAN DAN PENGEMBANGAN SISTEM INFORMASI INVENTARISASI MENGGUNAKAN DELPHI
}

\author{
Andrea Stevens Karnyoto \\ Staf Pengajar pada Program Studi Teknik Mesin, Fakultas Teknik, Universitas Kristen Indonesia Toraja, \\ E-Mail: karnyoto@gmail.com
}

\begin{abstract}
ABSTRAK
Penggunaan sistem informasi saat ini telah digunakan disegala bidang, tidak terkecuali pada bidan pencatatan inventaris ruangan dalam sebuah kantor atau organisasi. Penggunaan GUI(graphic user interface) yang baik dapat menjadi daya tarik tersendiri bagi para pengguna dalam menggunakan sistem informasi tersebut. Pengembangan sistem inventaris ini meliputi inventaris barang elektronik, orang, furniture maupun hal-hal lain yang dapat didata dalam sebuah ruangan. Sistem informasi dikembangkan menggunakan Delphi 2010 dengan menggunakan komponen graphic32 yang memungkinkan meletakkan objek-objek secara berlapis.

Dengan teknologi sistem informasi inventaris dapat membantu guna mengetahui barang apa saja yang ada dalam sebuah ruangan dan siapa saja yang bertugas dalam ruangan tersebut. Kemudahan mengatur objek sangat membantu pengguna dalam mempercepat kinerjanya.
\end{abstract}

Kata kunci : Inventarisasi, Delphi, Objek, Barang.

\section{PENDAHULUAN}

CV. Gersen melakukan pencatatan inventaris masih dilakukan secara manual. Pengecekan stok barang inventaris dilakukan rutin pada akhir bulan. Sehingga baru pada jangka waktu satu bulan informasi inventarisasi didapatkan. Keterbatasan informasi ini menyebabkan perusahaan tidak mempunyai informasi tentang posisi dan kondisi barang secara detail. Pengecekan yang tidak dilakukan secara detail ini menyebabkan pengelolaan barang inventaris perusahaan tidak berjalan dengan baik, sehingga sering terjadi selisih jumlah barang. Barang yang rusak atau barang yang keluar karena perbaikan atau perawatan barang tidak dapat terdeteksi. Selain itu, proses pencatatan inventaris yang masih manual dirasa kurang maksimal untuk pengelolaan inventaris.

Berdasarkan uraian diatas maka diperlukan suatu sistem informasi pengelolaan barang inventaris yang dapat dikelola secara efektif dan efisien untuk mengetahui laporan barang inventaris secara detail. Selain untuk pengelolaan aset, sistem ini dapat digunakan untuk transaksi pemesanan barang, maupun historis perawatan barang. Dengan sistem informasi pengelolaan barang inventaris diharapkan dapat memudahkan dalam pengelolaan barang inventaris tersebut, baik karena pergantian, pemesanan, perawatan maupun penghapusan barang. 
definisinya inventaris mengacu pada persediaan segala barang sumber daya yang digunakan dalam sebuah organisasi yang dapat berbentuk bahan mentah, pekerjaan dalam proses, barang jadi, suku cadang komponen, atau persediaan[6]. Inventaris ada untuk memungkinkan perusahaan memenuhi kebutuhan nasabah. Inventaris biasanya juga ada untuk memperlancar arus barang melalui proses produksi khususnya bagi pusat pekerjaan yang mempunyai ketergantungan. Inventaris merupakan daftar yang memuat semua barang milik perusahaan yang dipakai dalam melaksanakan tugas.

Tujuan dari penelitian ini adalah merancang sebuah sistem informasi inventarisasi yang dapat mencatat seluruh barang dalam sebuah gedung.

\section{METODE PENELITIAN}

\section{Lokasi dan Waktu Penelitian}

Penelitian ini telah dilakukan di Kota Makale yakni tepatnya di sebuah perusahaan CV. Gersen yang diimplementasikan dalam pengembangan sistem informasi Inventarisasi. Waktu penelitian 2 minggu.

\section{Sumber Data}

Dalam penelitian ini ada beberapa jenis data yang telah diambil sebagai bahan antara lain:

1. Data awal dari pengumpulan pustaka baik secara online maupun buku-buku.

2. Data yang berasal CV. Gersen.

3. Hasil data pembuatan program.
Tahap Penelitian

1. Studi kepustakaan, Pada tahap ini dilakukan pengumpulan bahan pustaka dan hasil-hasil penelitian pada jurnal-jurnal terdahulu, khususnya pada Sistem Informasi Travel. Informasi-informasi yang diperoleh kemudian dipelajari dan dirangkumkan sebagai referensi untuk membangun sistem ini.

2. Pengumpulan Data, Melakukan observasi dengan meminta field-field yang ada pada para karyawan.

3. Penyusunan Algoritma, Menentukan spesifikasi sistem yang akan digunakan dalam hal ini penyusunan algoritma pembuatan program.

4. Pembuatan Program Aplikasi, Pada tahap ini akan dibuat program yaitu dengan menggunakan perangkat lunak Yii Framework.

5. Eksperimen, Melakukan pengujian yang akan menguji efektifitas dan efisiensi.

\section{Strategi Pengembangan Sistem}

Dalam penelitian ini menggunakan standard coding, pair programming dan refactoring sehingga melibatkan beberapa orang yaitu:

Programmer : 1 Orang.

Analis sistem : $\quad 1$ Orang.

\section{Gambaran Umum Sistem}

Perangkat keras yang digunakan dalam proses pembuatan sistem ini adalah:

1. Komputer/desktop sebanyak 1 Buah (Proc. Intel Dual Core)

2. Laptop sebanyak 1 Buah(Proc. Intel Dual Core)

3. Switch Hub sebanyak 1 buah(Access Point) 
Perangkat lunak yang dibutuhkan dalam penelitian ini adalah:

1. Windows 7 Proffesional sebagai sistem operasinya.

2. Delphi 2010.

\section{Persyaratan Sistem}

1. Pada aplikasi harus menampilkan berikut.

a. Pengguna dapat membuka dan menyimpan berkas.

b. Pengguna dapat menambah, mengubah, menghapus objek dan ruangan.

c. Pengguna harus dapat dengan mudah memindahkan objek atau ruangan.

2. Penyimpanan berkas pada computer.

a. Berkas yang disimpan harus berupa file xml yang dikompres menjadi file .ask.

b. Menggunakan grafis yang baik sehingga pengguna dapat melakukan WYSIWYG(what you see is what you get).

\section{HASIL PENELITIAN}

Sistem informasi inventarisasi adalah sistem informasi yang digunakan untuk meninventarisir keadaan sebuah gedung, dimana pengguna dapat memasukkan komponen-komponen seperti orang, alat elektronik, lampu dan furnitur. Setiap elemen terdapat dalam sebuah ruangan dan berada dalam layer tertentu.

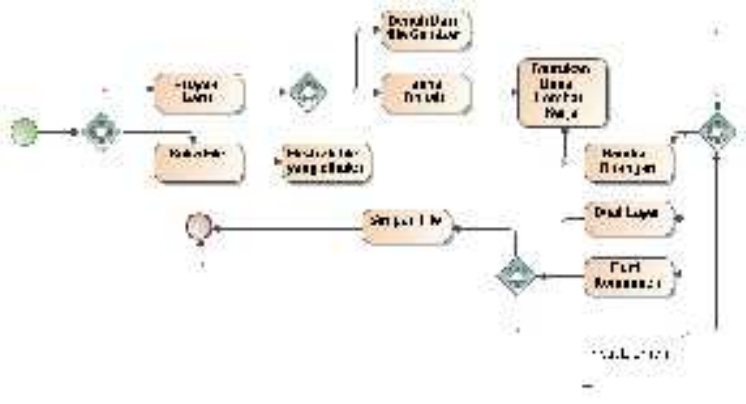

Gambar 4.1 Gambaran Umum
Pengguna dapat menambahkan layer, ruangan dan elemen-elemen dengan jumlah yang tidak terbatas dan hasil akhirnya dapat diketahui keberadaan tiap elemen tersebut.

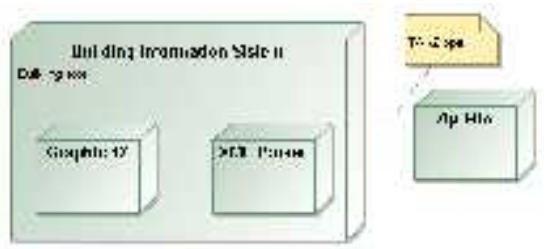

\section{Gambar 4.2 Diagram system deployment}

Gambar sebelumnya menjelaskan bahwa penyimpanan file menggunakan file XML yang akan dikompress sehingga menghasilkan sebuah file zip dan kemudian dapat dibuka kembali.

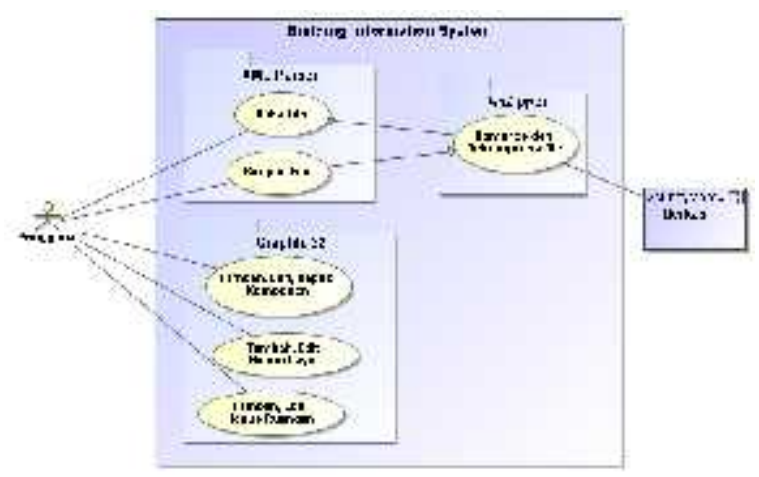

Gambar 4.3 Diagram Use Case

Gambar sebelumnya dijelaskan bahwa pengguna dapat menyimpan dan membaca file dari luar dan dapat menambah, mengedit dan menghapus elemen-elemen seperti komponen, layer dan ruangan.

Form didefinisikan oleh klas TForm yang disertakan dalam forms unit dari VCL. Klas TForm merupakan bagian dari hirarki kontrolkontrol windows, yang diawali dengan klas TWinControl (atau TwingetControl). Sedangkan frame didefinisikan oleh klas TFrame yang mempunyai fungsi seperti form. 
TFormBuilding adalah form utama dari program ini dan beberapa form pendukung seperti TFormProjectBaru, TFormDaftarKomponen serta TFormKomponen.

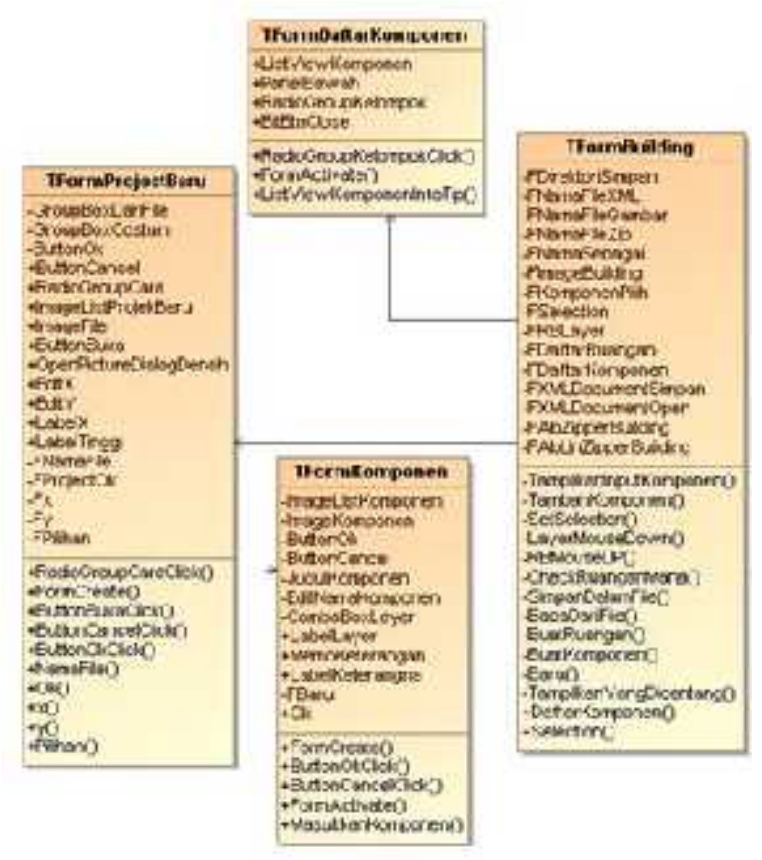

Gambar 4.4 Diagram Assosiasi antara

TFormBuilding dengan form-form pendukungnya

Klas-klas yang mendukung untuk jalannya sistem adalah klas TRuangan dan TKomponen yang digunakan untuk menyimpan seluruh informasi ruangan dan komponen. Kedua klas tersebut merupakan inheritas dari klas TComponent:

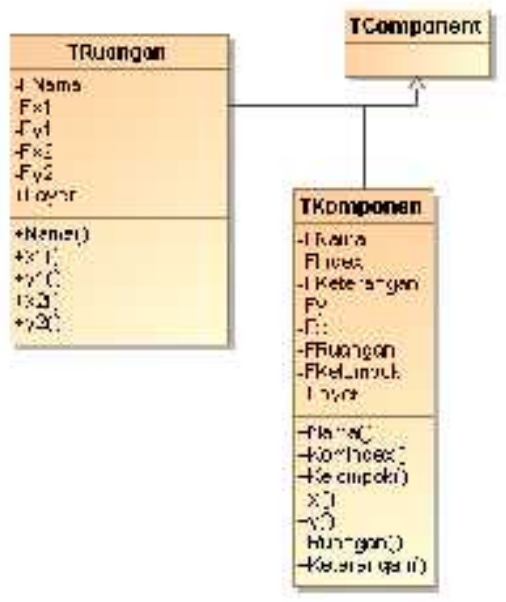

Gambar 4.5 Diagram Klas Inheritas TRuangan dan TKomponen

Diagram Business Proses Modelling Notation perlu dibuat karena dua alasan. Pertama, agar mudah dimengerti dan digunakan, yang kedua penggunaan diagram dapat mengekspressikan bisnis proses yang rumit. Berikut adalah bisnis proses dari alur kerja sistem.

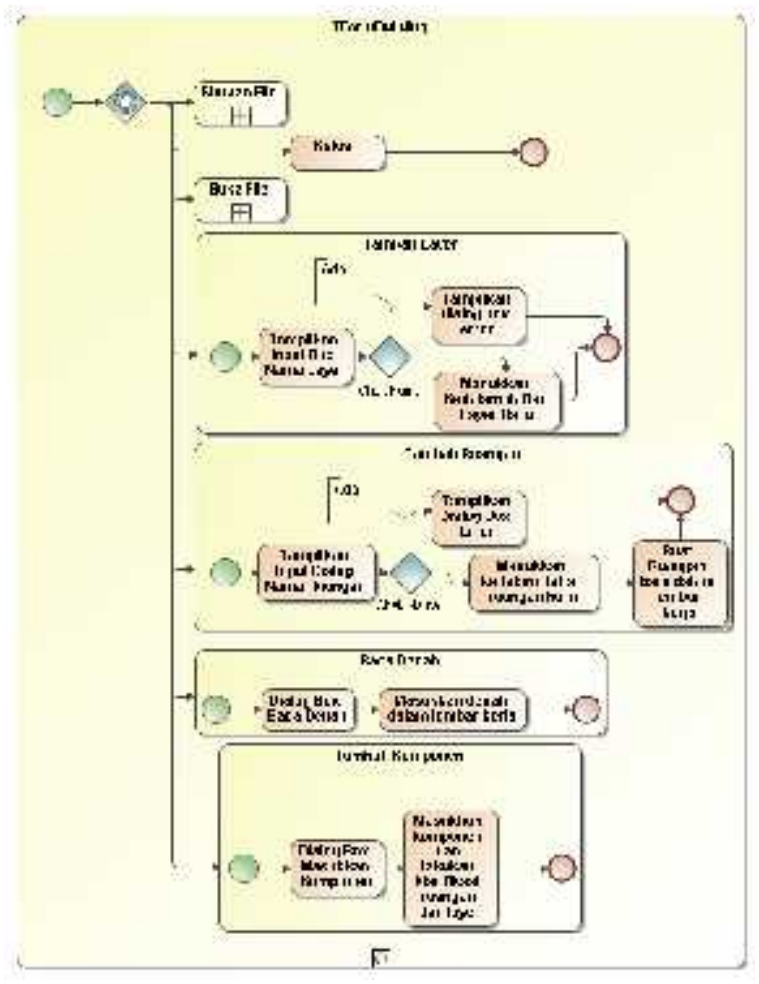

Gambar 4.6 Hubungan antar sub proses dalam klas TFormBuilding 


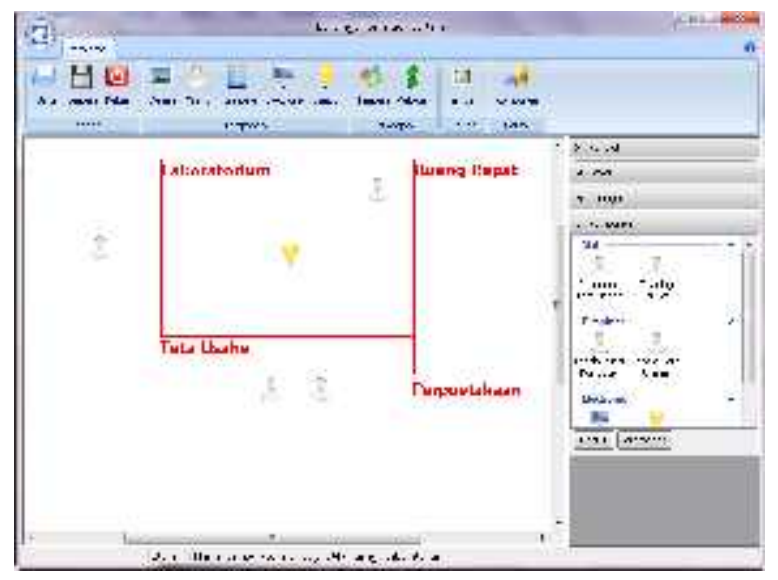

Gambar 4.7. Halaman utama dari sistem informasi Inventarisasi

Dari gambar diatas dapat dilihat halaman utama terdiri dari beberapa bagian, yaitu : halaman menu, halaman dock right side, dan lembar kerja.

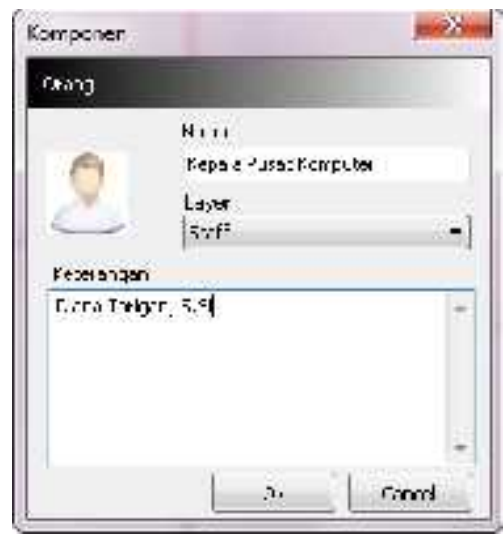

Gambar 4.8. Dialog tambah objek orang

Gambar 4.8 merupakan gambar penambahan komponen, contohnya adalah penambahan komponen orang. Kita dapat menempatkan pada layer tertentu dan dapat menambahkan jabatan serta nama orang.

Pada pemilihan layer, akan tampil seluruh layer yang telah dibuat. Keterangan bisa diisi apa saja yang berhubungan dengan objek tersebut.

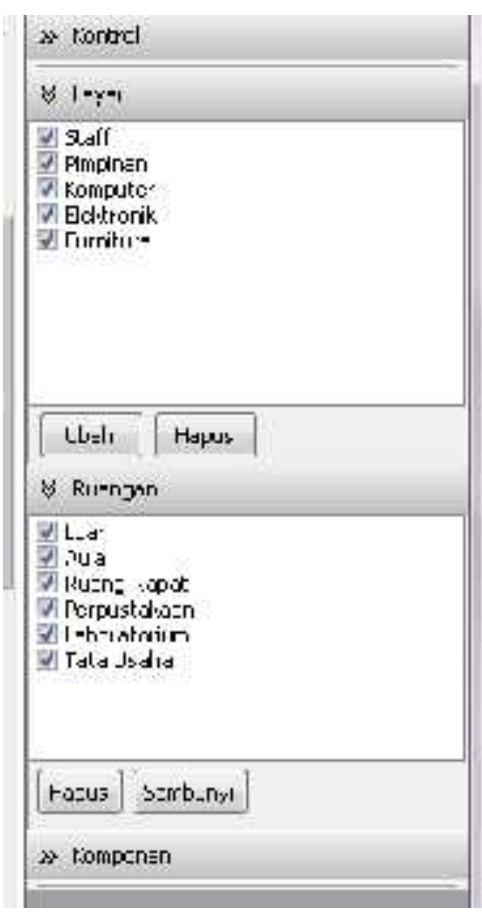

Gambar 4.9. Dock side yang berisi daftar ruangan dan layer serta daftar component.

Dari gambar sebelumnya dapat dilihat bahwa terdapat beberapa jendela docking yang berisi daftar-daftar komponen, ruangan dan layer sehingga pengguna dapat melihat komponenkomponen apa saja yang terdapat dalam sebuah layer.

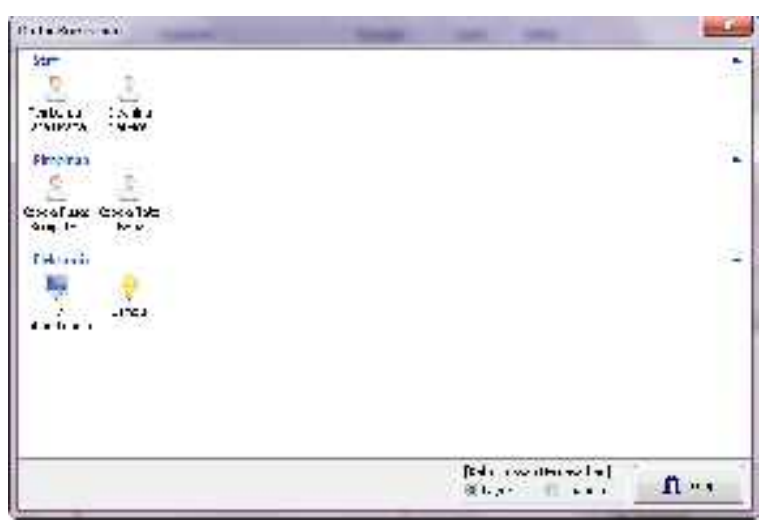

Gambar 4.10.Dialog komponen.

Gambar 4.10 memperlihatkan daftar komponen dalam beberapa layer sekaligus. Dapat dilihat bahwa kita dapat menambahkan layer ataupun 
komponen didalamnya, contohnya pada layer staff terdapat komponen pembantu tata usaha dan cleaning service dan begitu seterusnya.

\section{KESIMPULAN DAN SARAN}

Dengan teknologi sistem informasi inventaris dapat membantu guna mengetahui barang apa saja yang ada dalam sebuah ruangan dan siapa saja yang bertugas dalam ruangan tersebut. Kemudahan mengatur objek sangat membantu pengguna dalam mempercepat kinerjanya. Diharapkan adanya penelitian lanjutan untuk mengembangkan sistem informasi inventarisasi dengan menggunakan bahasa pemrograman yang lainnya.

\section{DAFTAR PUSTAKA}

[1] Chendramata, Aidil dan Priambodo, Adhityo., 2009, Keamanan Aplikasi dan Database Server, Departemen Komunikasi dan Informatika, Jakarta.

[2] Gronroos, christian., 2000, service management and marketing. Gava Media Yogyakarta.

[3] Herlambang, Soendoro, dan Haryanto Tanuwijaya, 2005. Sistem Informasi:
Konsep, Teknologi, dan Manajemen, Graha Ilmu, Yogyakarta.

[4] Jogiyanto, H, M., 1995, Analisa dan Desain Sistem Informasi, Andi Yogyakarta.

[5] Kadir, Abdul., 2003, Dasar Pemrograman Web Dinamis Menggunakan PHP, Andi Yogyakarta

[6] Krajewski, Lee J, P, Larry., 1999, Inventory Management Operations Management: Strategy and Analysis Edisi 5

[7] Kristanto, Adri., 2003, Perancangan Sistem dan Aplikasinya, Gava Media Yogyakarta.

[8] McLeod, Raymond, 2001, Sistem Informasi Manajemen, PT. Prenhalindo, Jakarta.

[9] Nugroho, Bunafit., 2005, Pengembangan Pemrogram WAP dan PHP, Gaya Media, Yogyakarta.

[10] Romeo., 2003, Testing dan Implementasi Sistem, Edisi Pertama, STIKOM, Surabaya.

[11] Rizky, Soetam, 2006. Interaksi Manusia dan Komputer. Surabaya : STIKOM.

[12] Tjiptono, Fandy dan Gregorius Chandra., 2005, Service, Quality dan Satisfaction. Yogyakarta:Andi. 